[Article]

\title{
$\mathrm{Na}$ 促进的 CuCoMn 催化剂催化生物质合成气合成高醇
}

\author{
叶同奇 ${ }^{1} \quad$ 张朝霞 $^{1}$ 徐 勇 $^{1} \quad$ 颜世志 $^{1} \quad$ 朱九方 $^{1} \quad$ 刘 勇 $^{2} \quad$ 李全新 ${ }^{1, *}$ \\ ('中国科学技术大学化学物理系, 生物质洁净能源安徽省重点实验室, 合肥 230026; \\ 2合肥天炎绿色能源开发有限公司, 合肥 230026)
}

\begin{abstract}
摘要: 研究钠促进的 CuCoMn 催化剂的特性及其在生物质气化合成气合成高醇中的应用. 研究了催化剂中 $\mathrm{Na}$ 含量及合成条件(温度、压力和空速)对生物质基合成气合成高醇性能的影响. 发现 CuCoMnNa 0 .1 催化剂较适 合高醇合成, 在 $300^{\circ} \mathrm{C}$ 以下, 随着温度的上升, 碳转化率增大, 而醇选择性降低. 压力的增加有利于醇的合成, 增大空速会明显降低碳转化率, 但醇时空产率则因转换频率的增加而增大. 在所考察的范围内, 醇产率最高达 到 $304.6 \mathrm{~g} \cdot \mathrm{kg}^{-1} \cdot \mathrm{h}^{-1}$, 其中 $\mathrm{C}_{2+}$ 高醇 $\left(\mathrm{C}_{2}-\mathrm{C}_{6}\right.$ 醇) 占 $64.4 \%$ ( $w$, 质量分数). 醇产物和烃产物均符合 ASF (AndersonSchulz-Flory)分布关系. 根据催化剂性能与表征分析, $\mathrm{Na}$ 的加入有利于提高生物质气化合成气合成高醇的选 择性和活性元素 $\mathrm{Cu} 、 \mathrm{Co}$ 的分散性. X射线光电子谱(XPS)测试结果显示反应后的催化剂表面上, $\mathrm{Cu}$ 以 $\mathrm{Cu}^{+}$和 $\mathrm{Cu}^{0}$ 的混合形式存在, 而 $\mathrm{Co}$ 则是 $\mathrm{Co}^{2+} / \mathrm{Co}^{3+}$ 和 $\mathrm{Co}^{\circ}$ 的混合物. 增加 $\mathrm{Na}$ 的含量, $\mathrm{Cu}^{\circ} / \mathrm{Cu}^{+}$比率和 $\mathrm{Co}^{\circ}$ 的强度均随 之减小.
\end{abstract}

关键词：生物质; 生物质合成气; 高醇; ASF分布; CuCoMnNa催化剂

中图分类号: 0643

\section{Higher Alcohol Synthesis from Bio-Syngas over Na-Promoted CuCoMn Catalyst}

\author{
YE Tong-Qi ${ }^{1} \quad$ ZHANG Zhao-Xia ${ }^{1} \quad$ XU Yong ${ }^{1} \quad$ YAN Shi-Zhi ${ }^{1}$ \\ ZHU Jiu-Fang ${ }^{1} \quad$ LIU Yong ${ }^{2}$ LI Quan-Xin ${ }^{1, *}$ \\ ('Anhui Key Laboratory of Biomass Clean Energy, Department of Chemical Physics, University of Science and Technology of China, \\ Hefei 230026, P. R. China; ${ }^{2}$ Hefei Tianyan Green Energy Development Co., Ltd., Hefei 230026, P. R. China)
}

\begin{abstract}
Na-promoted CuCoMn catalysts were successfully applied to the highly efficient production of higher alcohols from bio-syngas, which was derived from biomass gasification. The influence of $\mathrm{Na}$ content and synthesis conditions (temperature, pressure, and gas hourly space velocity (GHSV)) on higher alcohol synthesis was investigated. The CuCoMnNa ${ }_{0.1}$ catalyst gave the best performance for higher alcohol synthesis. Carbon conversion increased significantly with an increase in temperature at lower than $300{ }^{\circ} \mathrm{C}$ but alcohol selectivity showed an opposite trend. A higher pressure was found to be beneficial for higher alcohol synthesis. Increasing the GHSV reduced carbon conversion but increased the yield of higher alcohols. The maximum higher alcohol yield that was derived from bio-syngas was $304.6 \mathrm{~g} \cdot \mathrm{kg}^{-1} \cdot \mathrm{h}^{-1}$ with the $\mathrm{C}_{2+}$ alcohols $\left(\mathrm{C}_{2}-\mathrm{C}_{6}\right.$ higher alcohols) of $64.4 \%$ ( $w$, mass fraction) under the conditions used. The distributions of the alcohols and the hydrocarbons were consistent with Anderson-Schulz-Flory (ASF) plots. Adding $\mathrm{Na}$ to the CuCoMn catalysts led to an increase in the selectivity toward the higher alcohols and promoted the dispersion of the active elements, copper and cobalt. X-ray photoelectron spectroscopy (XPS) results suggested that $\mathrm{Cu}$ was present as a mixture of $\mathrm{Cu}^{+}$and $\mathrm{Cu}^{0}$ on the catalyst's surface after use and $\mathrm{Co}$ was
\end{abstract}

Received: January 20, 2011; Revised: April 1, 2011; Published on Web: April 22, 2011.

"Corresponding author. Email: liqx@ustc.edu.cn; Tel: +86-551-3601118.

The project was supported by the National Natural Science Foundation of China (50772107), National Key Basic Research Program of China (973) (2007CB210206) and National High-Tech Research and Development Program of China (863) (2009AA05Z435).

国家自然科学基金(50772107), 国家重点基础研究发展规划(973) (2007CB210206)及国家高技术研究发展计划(863) (2009AA05Z435)资助项目

(C) Editorial office of Acta Physico-Chimica Sinica 
present as a mixture of $\mathrm{Co}^{2+} / \mathrm{Co}^{3+}$ and $\mathrm{Co}^{\circ}$. With an increase in sodium addition the $\mathrm{Cu}^{\circ} / \mathrm{Cu}^{+}$ratio and the $\mathrm{Co}^{0}$ intensity both decreased.

Key Words: Biomass; Bio-syngas; Higher alcohol; ASF distribution; CuCoMnNa catalyst

\section{Introduction}

With the gradual depletion of fossil fuel resources, increasing energy demand and global climate change, renewable energy such as biomass energy will play a more important role in the future energy scenario of the world. ${ }^{1}$ Based on the thermochemical and biochemical processes, biomass can be converted into a wide range of liquid fuels (called as bio-fuels) or chemicals, such as bio-oil, bio-ethanol, bio-diesel, mixed alcohols, dimethyl ether (DME), etc., ${ }^{2,3}$ However, the raw bio-oil from various biomass by pyrolysis processes can not be directly used in gasoline or diesel engines because of low heating value, poor volatility, high viscosity, coking, corrosiveness, and high water content, and it must be upgraded prior to being used as a replacement for diesel and gasoline fuels. ${ }^{4}$ Another important route for the conversion of biomass to fuels is through its conversion to an intermediate synthesis gas, a mixture of $\mathrm{CO}$ and $\mathrm{H}_{2}$ named bio-syngas. Bio-syngas can be further catalytically converted into various bio-fuels and chemicals, especially to methanol, ethanol, mixed alcohols, and Fischer-Tropsch (FT) fuels. ${ }^{5}$ The unstinted feedstock type of biomass is one major advantage of this synthesis route..$^{6,7}$

With stringent restrictions on pollution emissions, alcohols appear to not only be environmentally friendly fuel additives, but also effective as potential octane number enhancer for motor fuels. As a potential alternative fuel/additive or chemical raw materials, the higher alcohols have many advantages including complete combustion, higher octane numbers, volatility control, lower toxic exhaust gas $\left(\mathrm{CO}, \mathrm{NO}_{x}\right)$ emissions, excellent substitutes for methyl tert-butyl ether (MTBE) and higher added value. ${ }^{8,9}$ So the catalytic conversion of synthesis gas to higher alcohols is now attracting renewed attention for both industrial application and fundamental research.

A wide range of homogeneous and heterogeneous catalysts for higher alcohol synthesis from syngas have been explored and well reviewed in recent papers. ${ }^{10}$ These catalysts can be broadly classified into four types: noble metals-based catalysts, ${ }^{11-13}$ modified Fischer-Tropsch catalysts, ${ }^{14-17}$ modified methanol catalysts, ${ }^{18-20}$ and Mo-based catalysts. ${ }^{21,22}$ Among those alcohol synthesis catalysts, copper modified Fischer-Tropsch catalysts have drawn a wide attention because of their high activity and selectivity, such as CuCo-based catalysts developed by Institut Francais du Petrole. ${ }^{23}$ For CuCo-based catalysts, cobalt was thought to provide the chain growth, while copper would be responsible for chain termination to produce alcohols. ${ }^{14}$ The component synergism result from interaction between $\mathrm{Cu}$ and $\mathrm{Co}$ plays a very important role in alcohol synthesis. ${ }^{16}$ However, the fact that these catalysts can be modified to increase their selec- tivity to higher alcohols suggests that they need to be further studied.

Generally speaking, a catalyst active for higher oxygenate synthesis must contain both adsorbed molecular $\mathrm{CO}$, and surface carbon species derived from dissociative adsorption of $\mathrm{CO}$. So the catalyst must be able to balance the $\mathrm{CO}$ dissociation and $\mathrm{CO}$ insertion that is necessary for the synthesis of higher alcohols. ${ }^{24}$ Thus besides copper and cobalt, a third component mainly including transition metal elements (such as $\mathrm{Zn}$, $\mathrm{Cr}, \mathrm{Mn}$, etc.) and a forth promoter of alkaline metal are also needed, ${ }^{14,15}$ although their functions are remained not quite clear. In the past decades, many attentions have been paid to the $\mathrm{Al}, \mathrm{Cr}$, and/or $\mathrm{Zn}$ promoted $\mathrm{CuCo}$ catalysts, including the preparation methods, ${ }^{25}$ alkali promote effects, ${ }^{15}$ and catalytic performances. ${ }^{26}$ Some new types of CuCo-based catalysts such as $\mathrm{CuCo} / \mathrm{CNTs}$ have also been reported. ${ }^{27}$ However, to the best of our knowledge, alkali-promoted $\mathrm{CuCoMn}$ catalysts for higher alcohol synthesis are rarely reported.

In our previous work, attention has been paid to produce syngas from the biomass gasification and the bio-oil reforming, both in lab and pilot plant scales. ${ }^{28-30}$ Present work aims to efficiently produce higher alcohols over the CuCoMn-based catalyst from the bio-syngas. Moreover, the influences of sodium addition on catalyst structure and catalytic performance of alcohol synthesis were also investigated. Biomass gasification-synthesis route could produce higher alcohols through the use of any biomass resource in large quantities. However, the bio-syngas conversion to higher alcohols remains challenging, and no commercial process exists so far although there is a growing worldwide interest in this topic for the past decades. Further researches and developments in catalyst and processing need to be achieved to make this conversion commercially attractive.

\section{Experimental}

\subsection{Catalyst preparation and characterization}

The CuCoMn-based mixed oxides catalysts with a settled molar ratio ( $\left.n_{\mathrm{Cu}}: n_{\mathrm{C} o}: n_{\mathrm{Mn}}=1: 1: 1\right)$ were prepared by the co-precipitation method from two aqueous solutions, one of which contained metal nitrate solution (A.R.) and the other contained sodium carbonate solution (A.R.). The metal nitrate solution was added quickly to the sodium carbonate solution at about $70{ }^{\circ} \mathrm{C}$. The coprecipitates were left to age in the mother liquor for $1 \mathrm{~h}$, dried at $120{ }^{\circ} \mathrm{C}$ for $12 \mathrm{~h}$, and calcined at $450{ }^{\circ} \mathrm{C}$ for $4 \mathrm{~h}$ in air to obtain the corresponding mixed oxide catalysts. The mixed oxides catalysts were finally crushed into 40-60 mesh for the higher alcohol syntheses. Catalysts before calcination were impregnated with different amounts of $\mathrm{Na}_{2} \mathrm{CO}_{3}$ (A.R.) for 
$\mathrm{CuCoMnNa} a_{0.1}$ and $\mathrm{CuCoMnNa} 0_{0.2}$. The molar ratios of $\mathrm{Cu} / \mathrm{Co} /$ $\mathrm{Mn} / \mathrm{Na}$ are $1: 1: 1: 0.1$ and $1: 1: 1: 0.2$ for $\mathrm{CuCoMnNa}_{0.1}$ and $\mathrm{CuCoMnNa} 0.2$, respectively.

The Brunauer-Emmett-Teller (BET) surface area and pore volume were determined by the $\mathrm{N}_{2}$ physisorption at $-196{ }^{\circ} \mathrm{C}$ using a COULTER SA 3100 analyzer. The X-ray diffraction (XRD) was measured on an $\mathrm{X}^{\prime}$ pert Pro Philips diffractrometer with a $\mathrm{Cu} K_{\alpha}$ radiation $(\lambda=0.154 \mathrm{~nm})$. The measurement conditions were in the range of $2 \theta=10^{\circ}-80^{\circ}$, step counting time $5 \mathrm{~s}$, and step size $0.017^{\circ}$ at $25^{\circ} \mathrm{C}$. The surface elements and their states were analyzed by X-ray photoelectron spectroscopy (XPS). The XPS measurements were performed on an ESCALAB250 (Thermo-VG Scientific, USA) spectrometer with Al $K_{\alpha}$ $(1486.6 \mathrm{eV})$ irradiation source. The $\mathrm{C} 1 s$ peak at $284.6 \mathrm{eV}$ was generally used as a calibration standard for determining the peaks' position and the elemental concentration.

\subsection{Reaction system for higher alcohol syntheses}

As shown in Fig.1, the performance of higher alcohol syntheses from the selected bio-syngas over the different $\mathrm{CuCoMn-}$ based catalysts was evaluated in a fixed-bed continuous-flow reactor using an on-line gas chromatograph (GC) detection system. The cylindrical reactor was constructed from $316 \mathrm{~L}$ with $40 \mathrm{~cm}$ length and an internal diameter of $1 \mathrm{~cm}$. Gas flow rates were regulated using Seven Star 17B mass flow controllers. Reactor pressure was maintained by a back pressure regulator. The catalyst bed temperature was measured during reactions using a type $\mathrm{K}$ thermocouple positioned within the reactor itself, near the center of the catalyst bed.

Usually, $1.0 \mathrm{~mL}$ catalyst, diluted with $2.0 \mathrm{~mL}$ Pyrex beads, was loaded in the reactor in any cases. Prior to kinetic tests the catalysts were activated with $5 \%$ (volume fraction) $\mathrm{H}_{2} / \mathrm{Ar}$ at $320{ }^{\circ} \mathrm{C}$ for $12 \mathrm{~h}$. Then, bio-syngas was conducted to the reactor for the higher alcohol syntheses under a setup synthesis condition. The syntheses were carried out under typical operating conditions: $T=260-320^{\circ} \mathrm{C}, p=3.0-7.0 \mathrm{MPa}$, GHSV (gas hourly space velocity) $=3000-9000 \mathrm{~h}^{-1}$. Quantitative product analysis from the reactor outlet stream was on-line sampled every

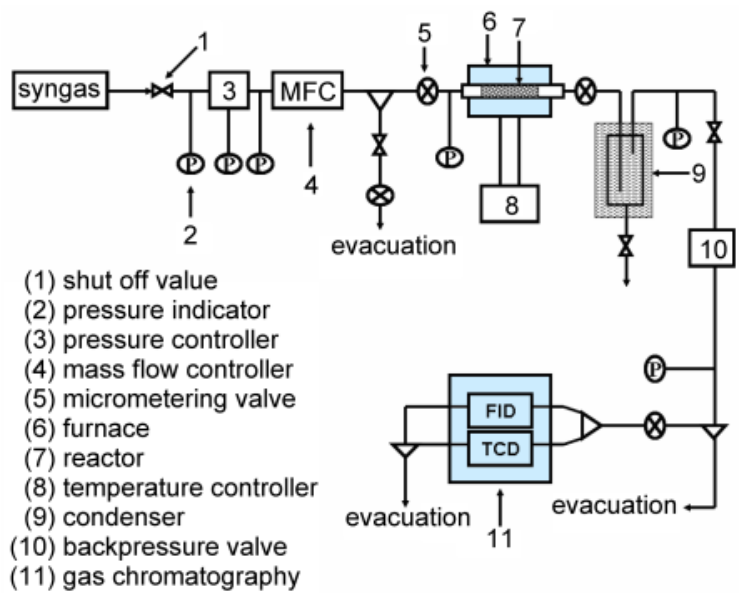

Fig.1 Schematic setup of the fixed-bed flow reaction system for mixed alcohol synthesis
15 min using two on-line gas chromatographs (GC1 and GC2). The gases of $\mathrm{H}_{2}, \mathrm{CO}$, and $\mathrm{CO}_{2}$ were detected by $\mathrm{GC} 1$ (Model: SP6890, column: TDX-01) with a thermal conductivity detector (TCD), and gaseous hydrocarbons were detected by GC2 (Model: SP6890, column: PorapakQ-S, USA) with a flame ionization detector (FID). The condensable vapors (mainly consisting of higher alcohols and water) were cooled into a liquid tank and then detected offline by GC2 with a FID. The performance of higher alcohol syntheses was evaluated by the carbon conversion $\left(C_{\mathrm{C}}\right)$, space time yield of higher alcohols $\left(Y_{\mathrm{Alc}}, \mathrm{g} \cdot\right.$ $\left.\mathrm{kg}^{-1} \cdot \mathrm{h}^{-1}\right)$, selectivity of alcohols $\left(S_{\mathrm{Alc}}\right)$, and hydrocarbons $\left(S_{\mathrm{Hc}}\right)$, according to the following equations:

$$
\begin{aligned}
C_{\mathrm{C}} & =\frac{n_{\mathrm{CO}_{\text {in }}}-n_{\mathrm{CO}_{\text {out }}}}{n_{\mathrm{CO}_{\text {in }}}} \times 100 \% \\
Y_{\mathrm{Alc}} & =\frac{m_{\mathrm{Alc}}}{m_{\mathrm{Cat}} \times t_{\text {reaction }}} \\
S_{\mathrm{Alc}} & =\frac{C_{\mathrm{Alc}}}{C_{\mathrm{Alc}}+C_{\mathrm{Hc}}+C_{\mathrm{CO}_{2}}} \times 100 \% \\
S_{\mathrm{Hc}} & =\frac{C_{\mathrm{Hc}}}{C_{\mathrm{Alc}}+C_{\mathrm{Hc}}+C_{\mathrm{CO}_{2}}} \times 100 \%
\end{aligned}
$$

\subsection{Feedstock for higher alcohol syntheses}

In this work, one bio-syngas derived from the biomass gasification was used for the higher alcohol synthesis. The bio-syngas was produced by biomass gasification in a circulating fluidized bed using rice husks with the gasification temperature of $1000-1300^{\circ} \mathrm{C}$ and pressure of 1.5-3.0 MPa, followed by conditioning the syngas via water-gas shift (WGS) reaction and purification processes. ${ }^{31}$ The main composition of the bio-syngas is $\mathrm{H}_{2} 62.80 \%, \mathrm{CO} 30.89 \%, \mathrm{CO}_{2} 2.96 \%, \mathrm{~N}_{2} 1.75 \%, \mathrm{CH}_{4} 1.20 \%$, and others $0.40 \%$ (volume fraction).

\section{Results and discussion}

\subsection{Catalyst screening}

Catalysts were prepared with the sodium promoter concentration varied from 0 to $6 \%$ (molar fraction) and compared under constant conditions of $5.0 \mathrm{MPa}, 300{ }^{\circ} \mathrm{C}$ and gas hourly space velocity (GHSV) of $6000 \mathrm{~h}^{-1}$. The CO hydrogenation performances summarized in Table 1 show that the catalyst with a $3 \%$ (molar fraction) Na loading produces the highest alcohol synthesis activity. The overall activity of the promoted catalyst increases as the $\mathrm{Na}$ loading increases from 0 to $3 \%$, showing the highest carbon conversion of $36.2 \%$, while decreases rapidly to $24.2 \%$ when the Na loading further increases to $6 \%$. As shown in Table 1, Na promoter not only influences catalytic ac-

\begin{tabular}{|c|c|c|c|c|c|c|}
\hline \multirow{2}{*}{ Catalyst } & \multirow{2}{*}{$x_{\mathrm{Na}} / \%$} & \multirow{2}{*}{$C_{\mathrm{C}} / \%$} & \multicolumn{3}{|c|}{$S_{\mathrm{C}} / \%$} & \multirow{2}{*}{$Y /\left(\mathrm{g} \cdot \mathrm{kg}^{-1} \cdot \mathrm{h}^{-1}\right)$} \\
\hline & & & $\mathrm{C}_{x} \mathrm{H}_{y}$ & $\mathrm{ROH}$ & $\mathrm{CO}_{2}$ & \\
\hline $\mathrm{CuCoMn}$ & 0 & 30.6 & 51.7 & 24.3 & 24.0 & 132.0 \\
\hline $\mathrm{CuCoMnNa} \mathrm{a}_{0.1}$ & 3 & 36.2 & 20.5 & 46.8 & 32.7 & 258.0 \\
\hline $\mathrm{CuCoMnNa} \mathrm{a}_{0.2}$ & 6 & 24.2 & 19.3 & 48.8 & 31.9 & 212.2 \\
\hline
\end{tabular}
tivity, but also promotes alcohol selectivity and inhibits hydro-

Table 1 Performance of higher alcohol synthesis for various sodium loading

synthesis conditions: $T=300{ }^{\circ} \mathrm{C}, p=5.0 \mathrm{MPa}, \mathrm{GHSV}=6000 \mathrm{~h}^{-1}$ 
carbon synthesis in $\mathrm{CO}$ hydrogenation reaction. The total alcohol selectivity $\left(S_{\mathrm{C}}\right)$ increased from $24.3 \%$ to $46.8 \%$ as Na loading $\left(x_{\mathrm{Na}}\right)$ increased from 0 to $3 \%$, while the hydrocarbon selectivity decreased from $51.7 \%$ to $20.5 \%$, respectively.

Alkali addition has been demonstrated to influence the catalyst activity through two typical ways. One is to facilitate adsorption of CO molecules on the catalyst surface ${ }^{16,32}$ thus resulting in a higher efficiency of hydrogenation, as the $3 \% \mathrm{Na}$ loading catalyst shows. The other is to cover the active sites which induce a decrease of catalytic activity. As $\mathrm{Boz}^{14}$ reported that the addition of $\mathrm{K}$ to the $\mathrm{CuCoZnAl}$ catalyst resulted in the suppression of overall catalytic activity on higher alcohol synthesis.And Chen et al. ${ }^{33}$ proved the excessive $\mathrm{K}_{2} \mathrm{O}$ loading induced a serious accumulation of potassium on the catalyst surface by XPS characterization. The presence of $\mathrm{Na}$ additive strongly suppresses the formation of hydrocarbons (Table 1), possibly due to the decrease in the availability of $\mathrm{H}^{*}$ atoms required for termination of growth chains via hydrogen addition reactions to produce paraffins. ${ }^{34,35}$ However, another view proposed by Courty et al. ${ }^{36}$ for the enhanced alcohol selectivity is that alkali addition suppresses alcohol dehydration by suppressing the acidic nature of the catalyst.

\subsection{Performance of higher alcohol synthesis}

Table 2 shows the influence of operating conditions (temperature, pressure, and GHSV) on the higher alcohol synthesis using bio-syngas over the $3 \% \mathrm{Na}$ promoted catalyst under the synthesis conditions: $T=260-320^{\circ} \mathrm{C}, p=3.0-7.0 \mathrm{MPa}$, and GHSV $=3000-9000 \mathrm{~h}^{-1}$. Commonly, temperature is one of the most critical reaction parameters in the higher alcohol synthesis, which significantly affects the rate of kinetically controlled synthesis reactions. In the lower temperature region, an increasing temperature is conducive to the dissociative adsorption of $\mathrm{CO}$ and $\mathrm{H}_{2}$ while promoting the formation of the specified intermediates (e.g., alkyls and formyl species), ${ }^{37,38}$ which leads to an increase of the $\mathrm{CO}$ hydrogenation. However, another important characteristic of higher alcohol synthesis is the unavoidable production of a large amount of hydrocarbons, and exorbitant temperature will greatly decrease the alcohol selectivity and enhance the formation of hydrocarbons. ${ }^{39,40}$ Consequently, considering the balance of productivity and selectivity, an appropriate temperature needs to be determined through experi- mentation and then to be closely controlled at this value in the reactor.

As shown in Table 2, the carbon conversion significantly increased from $11.9 \%$ to $59.7 \%$ with a rising temperature from 260 to $320{ }^{\circ} \mathrm{C}$. An increasing trend was also observed for the space time yield of higher alcohols in this range. The selectivity towards total alcohols $\left(\mathrm{C}_{1}-\mathrm{C}_{6}\right.$ alcohols) decreased from $61.8 \%$ to $28.3 \%$ with a rising temperature versus an opposite trend for the hydrocarbons selectivity. In the hydrocarbon distribution, products were almost $\mathrm{C}_{1}-\mathrm{C}_{4}$ gaseous hydrocarbons besides a small quantity of liquid hydrocarbons. In the alcohols products, the $\mathrm{C}_{2+}$ alcohols $\left(\mathrm{C}_{2}-\mathrm{C}_{6}\right.$ higher alcohols $)$ contained with a mass fraction of $28.7 \%-63.9 \%(w)$ and main alcohol products were methanol, ethanol, and propanol under the tested synthesis conditions. When the temperature was fixed at $300{ }^{\circ} \mathrm{C}$, the carbon conversion and space time yield ascended monotonously as pressure increased, for the synthesis reactions involved a decrease in the number of molecules. In contrast, the carbon conversion decreased with the increase of the gas hourly space velocity, which was accompanied by an increase of the space time yield of higher alcohol. The negative impact of GHSV on the carbon conversion may result from shortening residence time in the catalyst bed, while the positive impact on the fuel yield can arise from the increase of the turnover frequency of the synthesis products with increasing GHSV. The maximum higher alcohol yield from bio-syngas was about $304.6 \mathrm{~g} \cdot \mathrm{kg}^{-1} \cdot \mathrm{h}^{-1}$ with the alcohol selectivity of $50.1 \%$ and $\mathrm{C}_{2+}$ alcohols distribution of $64.4 \%(w)$ within our studied range. Apart from the alcohol and hydrocarbon products, only a small amount of other compounds including aldehydes, ketones, esters, and ethers were also detected.

Moreover, the catalytic stability in the higher alcohol synthesis process was tested by measuring the $\mathrm{CO}$ conversion, selectivity of alcohols and hydrocarbons, yields of alcohols as a function of time on stream. As shown in Fig.2, the activity increases initially until it reaches the maximum at about 4-6 h of time on stream, and then it decreases very slowly in our tested $80 \mathrm{~h}$. The selectivity of hydrocarbons increases gradually, however, both the alcohol selectivity and yields follow a trend of decrease. A long-term $(80 \mathrm{~h})$ reaction test led to about 5\%-8\% reduction in the higher alcohol synthesis activity compared to

Table 2 Performance of higher alcohol synthesis using bio-syngas over $\mathrm{CuCoMnNa}_{0.1}$ catalyst

\begin{tabular}{|c|c|c|c|c|c|c|c|c|}
\hline \multicolumn{3}{|c|}{ Synthesis conditions } & \multirow{2}{*}{$C_{\mathrm{C}} / \%$} & \multicolumn{3}{|c|}{$S_{\mathrm{c}} / \%$} & \multirow{2}{*}{$\frac{Y /\left(\mathrm{g} \cdot \mathrm{kg}^{-1} \cdot \mathrm{h}^{-1}\right)}{\mathrm{ROH}}$} & \multirow{2}{*}{$w\left(\mathrm{C}_{2+} \mathrm{OH}\right) / \%$} \\
\hline$T /{ }^{\circ} \mathrm{C}$ & $p / \mathrm{MPa}$ & $\mathrm{GHSV} / \mathrm{h}^{-1}$ & & $\mathrm{C}_{x} \mathrm{H}_{y}$ & $\mathrm{ROH}$ & $\mathrm{CO}_{2}$ & & \\
\hline 260 & 5.0 & 6000 & 11.9 & 9.1 & 61.8 & 29.1 & 102.9 & 28.7 \\
\hline 280 & 5.0 & 6000 & 18.8 & 15.7 & 53.9 & 30.4 & 152.3 & 40.2 \\
\hline 300 & 5.0 & 6000 & 36.2 & 20.5 & 46.8 & 32.7 & 258.0 & 63.9 \\
\hline 320 & 5.0 & 6000 & 59.7 & 37.6 & 28.3 & 34.1 & 271.8 & 62.0 \\
\hline 300 & 3.0 & 6000 & 27.2 & 41.6 & 34.4 & 24.0 & 138.2 & 55.8 \\
\hline 300 & 7.0 & 6000 & 37.1 & 16.9 & 50.1 & 33.0 & 304.6 & 64.4 \\
\hline 300 & 5.0 & 3000 & 57.1 & 24.0 & 46.5 & 29.5 & 206.6 & 58.2 \\
\hline 300 & 5.0 & 9000 & 23.3 & 17.2 & 49.5 & 33.3 & 287.0 & 64.1 \\
\hline
\end{tabular}




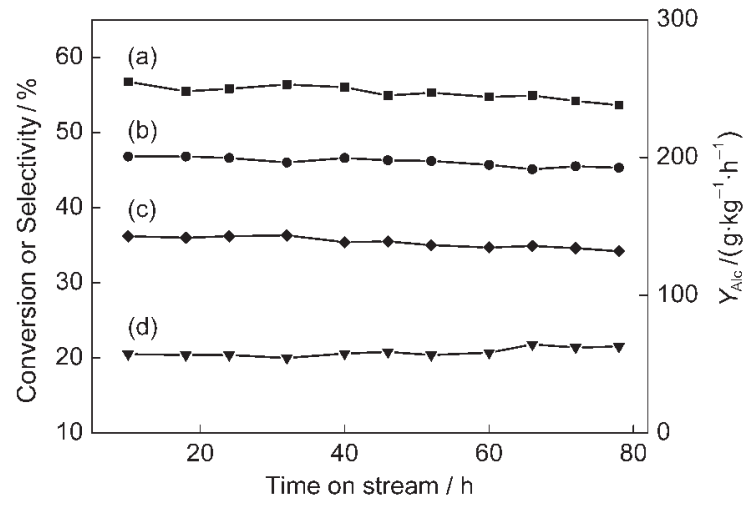

Fig.2 Stability of the $\mathrm{CuCoMnNa}$.1 catalyst in the higher alcohol synthesis

(a) yield of higher alcohols, (b) selectivity of alcohols, (c) carbon conversion, (d) selectivity of hydrocarbons; synthesis conditions: $T=300^{\circ} \mathrm{C}$, $\mathrm{GHSV}=6000 \mathrm{~h}^{-1}, p=5.0 \mathrm{MPa}$

the maximum values. Generally, the slow catalyst inactivation observed in the higher alcohol synthesis process could mainly

(a)
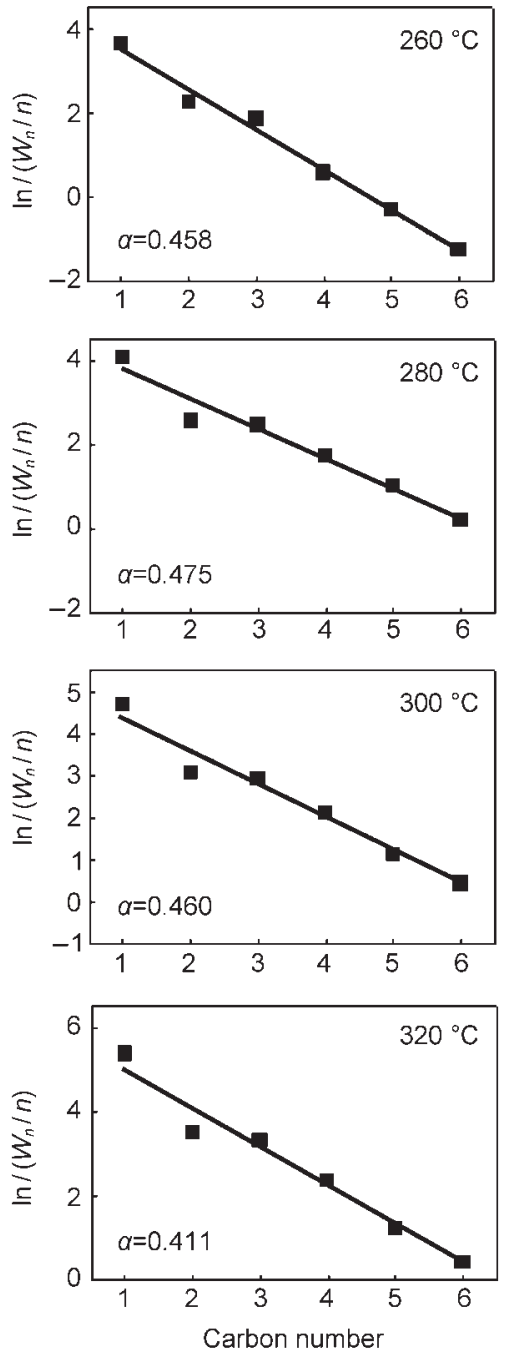

ascribe to the sintering of active sites and deposition of the carbon ${ }^{16}$ on the catalysts.

As shown in Fig.3, both alcohols and hydrocarbon products were consistent with the ASF distributions. ${ }^{41}$ Interestingly, the rate of methanol formation was also in line with higher alcohols according to the ASF distribution. Using the ASF distribution we determined the chain growth probability $(\alpha)$ from the slope of the linear part of the plot. The $\alpha$ values of alcohols were found to be increased (from 0.196 to 0.362 ) while those of hydrocarbons remained nearly constant $(\alpha=0.460 \pm 0.020)$ for the $\mathrm{CuCoMnNa}_{0.1}$ catalyst when temperature increased from 260 to $300{ }^{\circ} \mathrm{C}$. This fact can be taken as an indirect evidence that alcohols and hydrocarbons were formed on different active sites for CuCo-based catalysts as $\mathrm{Boz}^{14}$ proposed.

\subsection{Catalyst characterization}

Some of important physical and chemical properties, including BET surface area, pore volume, and the size of the crystallites were investigated for the CuCoMn-based catalysts before and after used. As shown in Table 3, the doping of sodium in

(b)
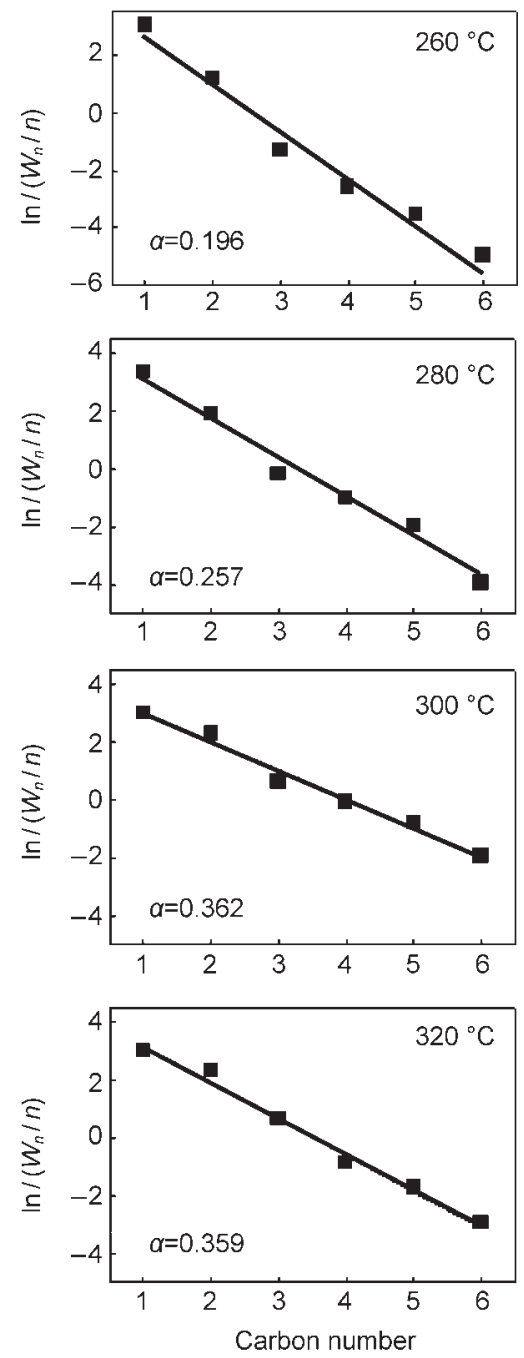

Fig.3 Anderson-Schulz-Flory plots of (a) hydrocarbons and (b) alcohols over $\mathrm{CuCoMnNa}_{0.1}$ catalyst at different temperatures 
Table 3 Texture parameters of fresh and used CuCoMn-based catalysts

\begin{tabular}{|c|c|c|c|c|c|}
\hline Sample & & $S_{\mathrm{BET}} /\left(\mathrm{m}^{2} \cdot \mathrm{g}^{-1}\right)$ & $V_{\text {pore }} /\left(\mathrm{cm}^{3} \cdot \mathrm{g}^{-1}\right)$ & $D_{\text {pore }} / \mathrm{nm}$ & $d_{\mathrm{XRD}} / \mathrm{nm}$ \\
\hline \multirow[t]{2}{*}{ CuCoMn } & fresh & 111 & 0.24 & 6.7 & 5.64 \\
\hline & used & 4.9 & 0.10 & 30.1 & $6.61^{\circ}$ \\
\hline \multirow[t]{2}{*}{$\mathrm{CuCoMnNa} \mathrm{Mal}_{0.1}$} & fresh & 75 & 0.23 & 9.4 & 5.31 \\
\hline & used & 14 & 0.12 & 22.7 & $6.42^{\circ}$ \\
\hline \multirow[t]{2}{*}{$\mathrm{CuCoMnNa} \mathrm{M}_{0.2}$} & fresh & 71 & 0.21 & 10.4 & 5.42 \\
\hline & used & 12 & 0.13 & 25.7 & $6.46^{\circ}$ \\
\hline
\end{tabular}

the catalyst induced an obviously decrease of BET surface area and increase of pore size. The BET surface area decreased from 111 to $71 \mathrm{~m}^{2} \cdot \mathrm{g}^{-1}$, while the pore size increased from 6.7 to $10.4 \mathrm{~nm}$ with the Na loading from 0 to $6 \%$. Such an effect may be related to the clogging of micropores caused by sodium carbonate when considering the adsorption/desorption isotherm data. ${ }^{16}$

Fig. 4 shows the XRD patterns of the fresh $\mathrm{CuCoMnNa} \mathrm{Cu}_{0.1}$ catalyst, the reduced ones (pure $\mathrm{H}_{2}, 320{ }^{\circ} \mathrm{C}, 8 \mathrm{~h}$ ), and the used ones $\left(T=300{ }^{\circ} \mathrm{C}, p=5.0 \mathrm{MPa}\right.$, GHSV $\left.=6000 \mathrm{~h}^{-1}, t=20 \mathrm{~h}\right)$ for higher alcohol synthesis, corresponding patterns of $\mathrm{CuCuMn}$ catalyst were also shown. For the fresh samples, all the diffraction peaks can be assigned to spinal $\mathrm{CuCoMnO}_{4}$ (JCPDS 47-0324). ${ }^{42}$ Formation of the mixture oxide may be the cause of the excellent catalytic stability of CuCoMn catalysts. The addition of $\mathrm{Na}$ promoter did not present significant structural modification when compared with the diffractogram of none sodium addition sample. As suggested by Dalmon et al. ${ }^{16}$ for the CoAl-based catalysts, alkali doping probably just coats the surface as sodium carbonate. For the catalysts reduced by $\mathrm{H}_{2}$, $\mathrm{Cu}$ (JCPDS 04-0836) and MnO (JCPDS 01-1206) were detected, but none of Co signals was found suggesting a high dispersion of Co species under reduction conditions. However, after being used at $300{ }^{\circ} \mathrm{C}$ for higher alcohol synthesis, the diffraction peaks of $\mathrm{Co}_{3} \mathrm{O}_{4}$ appeared probably due to a slightly sintering. Moreover, the $\mathrm{Cu}$ particle sizes for the used catalysts calculated by XRD line widths of the strongest peak $\left(2 \theta=43.4^{\circ}\right)$ using Debye-Scherrer equation are shown in Table 3. Compared with the none-sodium addition catalyst, the Na-promoted sample showed a smaller $\mathrm{Cu}$ particle size. It is well-known that catalysts with small crystallite sizes have an advantage to produce more alcohols while larger crystallites to hydrocarbons. ${ }^{43}$

The alterations of the atomic states on the catalyst's surfaces before and after the synthesis reaction were investigated by the
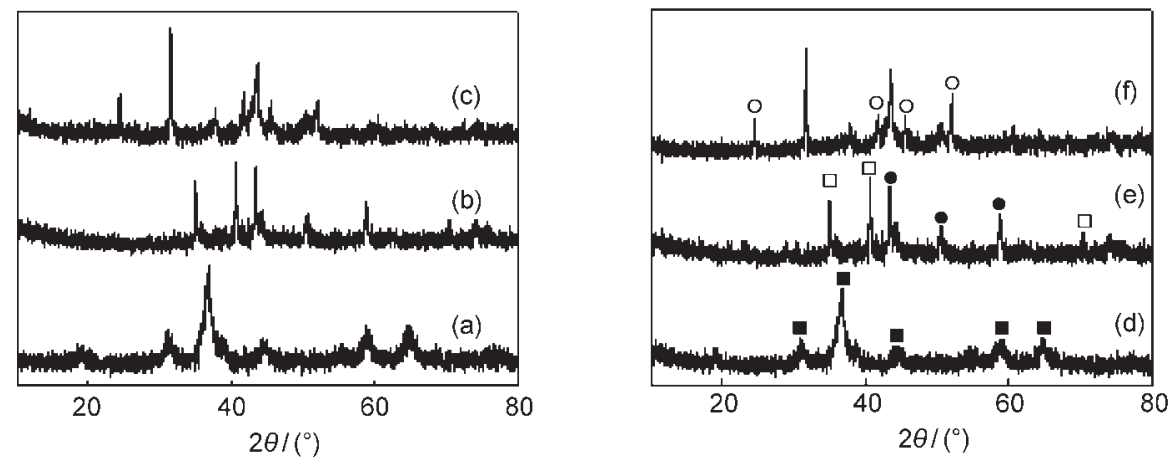

Fig.4 XRD patterns of (a) fresh CuCoMn catalyst, (b) reduced CuCoMn catalyst, (c) used CuCoMn catalyst,

(d) fresh CuCoMnNa $a_{0.1}$ catalyst, (e) reduced CuCoMnNa $\mathrm{Cu}_{0.1}$ catalyst, and (f) used CuCoMnNa.1 catalyst

- $\mathrm{CuCoMnO}_{4}, \bullet \mathrm{Cu}, \square \mathrm{MnO}, \circ \mathrm{Co}_{3} \mathrm{O}_{4}$; synthesis conditions: (b) $T=300{ }^{\circ} \mathrm{C}$, pure $\mathrm{H}_{2}, p=0.5 \mathrm{MPa}$, (c) $T=300{ }^{\circ} \mathrm{C}, \mathrm{GHSV}=6000 \mathrm{~h}^{-1}, p=5.0 \mathrm{MPa}, \mathrm{t}=20 \mathrm{~h}$, (e) $T=300{ }^{\circ} \mathrm{C}$, pure $\mathrm{H}_{2}, p=0.5 \mathrm{MPa}$, (f) $T=300{ }^{\circ} \mathrm{C}$, GHSV $=6000 \mathrm{~h}^{-1}, p=5.0 \mathrm{MPa}, t=20 \mathrm{~h}$
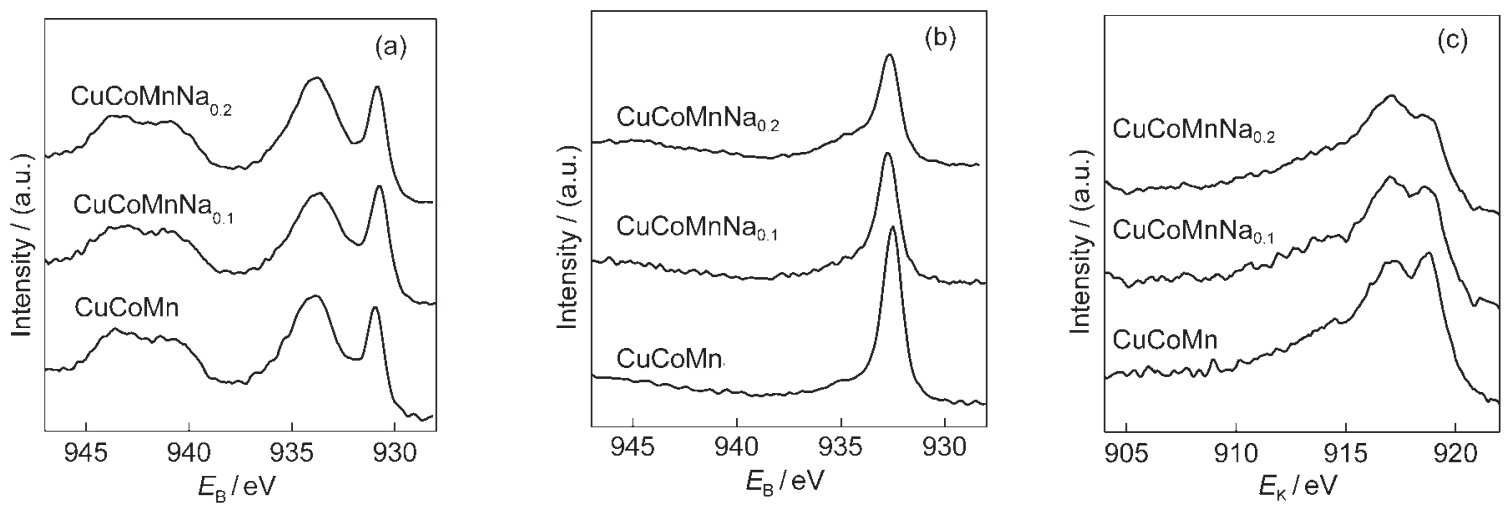

Fig.5 Cu $2 p$ XPS spectra and Cu $L M M$ Auger electron spectra for different catalysts

(a) $\mathrm{Cu} 2 p$ XPS spectra for fresh catalysts, (b) $\mathrm{Cu} 2 p$ XPS spectra for used catalysts, (c) $\mathrm{Cu} L M M$ Auger electron spectra for used catalysts; synthesis conditions: $T=300{ }^{\circ} \mathrm{C}, p=0.5 \mathrm{MPa}, \mathrm{GHSV}=6000 \mathrm{~h}^{-1}, t=20 \mathrm{~h}$ 

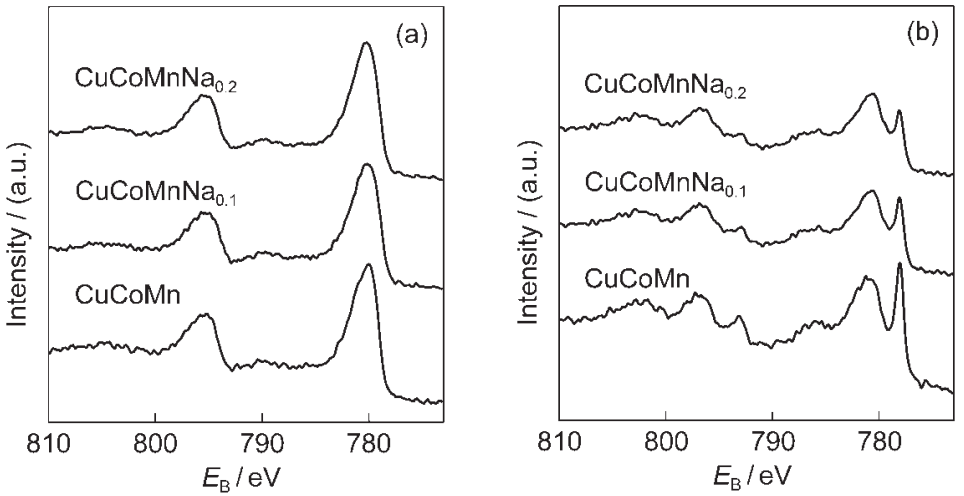

Fig.6 Co $2 p$ XPS spectra for different catalysts

(a) Co $2 p$ XPS spectra for fresh catalysts, (b) Co $2 p$ XPS spectra for used catalysts; synthesis conditions: $T=300{ }^{\circ} \mathrm{C}, p=0.5 \mathrm{MPa}, \mathrm{GHSV}=6000 \mathrm{~h}^{-1}, t=20 \mathrm{~h}$

XPS measurements. As can be seen from Fig.5(a), the binding energy at about 930.8 and $933.7 \mathrm{eV}$ were observed for the pristine catalysts, which were assigned to the main line of $\mathrm{Cu}^{+}\left(2 p_{32}\right)$ and $\mathrm{Cu}^{2+}\left(2 p_{3 / 2}\right){ }^{44}$ respectively. Note that no reduction was employed on the catalysts, the presence of $\mathrm{Cu}^{+}$should attribute to the internal reduction of $\mathrm{Mn}^{3+}$, which has been proved by Yang et al. ${ }^{42}$ After the higher alcohol synthesis, the $\mathrm{Cu}^{2+}$ on the surface was reduced as Fig.5(b) shows. For the $\mathrm{Cu}^{0}$ and $\mathrm{Cu}^{+}$species can not be distinguished by the $2 p_{3 / 2}$ peak, Fig.5(c) shows the $\mathrm{Cu} L M M$ Auger electron spectra. It can be found that the used samples exhibit a double peak structure at kinetic energy values of 917.0 and $918.7 \mathrm{eV}$. According to Velu et al., ${ }^{44}$ these two peaks are corresponding to $\mathrm{Cu}^{+}$and $\mathrm{Cu}$ metal, respectively. With the increasing of sodium addition, the $\mathrm{Cu}^{+} / \mathrm{Cu}^{0}$ ratio increased, indicating the stabilization of $\mathrm{Cu}^{+}$species. A similar internal reduction effect was also observed on Co as Fig.6(a) shows, the weak satellite of $\mathrm{Co}^{3+}\left(2 p_{2 / 3}\right)$ was about $10 \mathrm{eV}$ higher than its main peak, not as commonly $6 \mathrm{eV}$. In addition, the very weak satellite shows a mixture of $\mathrm{Co}^{2+}$ and $\mathrm{Co}^{3+} \cdot{ }^{44}$ After the higher alcohol synthesis, as Fig.6(b) shows, a peak at binding energy $\left(E_{\mathrm{B}}\right)$ value of $778.8 \mathrm{eV}$ appeared, which could be assigned to $\mathrm{Co}^{0}$ species. However, the intensity of $\mathrm{Co}^{0}$ decreased with increasing the $\mathrm{Na}$ content. Some argue that $\mathrm{Co}^{\circ}$ is an active site of hydrogenation that tends to formation of hydrocarbons. $^{14}$

\section{Conclusions}

This work reports that higher alcohols can be efficiently produced from bio-syngas derived from the biomass gasification using Na-promoted CuCoMn catalysts. Appropriate amount of sodium enhances the total alcohol selectivity and productivity. $\mathrm{CuCoMnNa}_{0.1}$ catalyst is moderately selective for production of higher alcohols under mild conditions. It was found that alcohol selectivity decreased monotonously with the temperature increasing, while the mass fraction of $\mathrm{C}_{2+}\left(\mathrm{C}_{2}-\mathrm{C}_{6}\right)$ alcohols in total alcohol products increased. The optimum temperature was about $300{ }^{\circ} \mathrm{C}$ based on the higher alcohol selectivity and productivity. The maximum higher alcohol yield from the biosyngas was about $304.6 \mathrm{~g} \cdot \mathrm{kg}^{-1} \cdot \mathrm{h}^{-1}$ with the alcohol selectivity of $50.1 \%$ and $\mathrm{C}_{2+}$ alcohols distribution of $64.4 \%(w)$ within the tested conditions. Considering of the ASF distributions, there probably exists two different active sites with two distinctly chain growth probability factors for alcohols and hydrocarbons, respectively. According to XRD analysis, $\mathrm{CuCoMnO}_{4}$ mixture oxide is the dominant phase for the fresh catalysts. XPS results suggest that $\mathrm{Cu}$ presents as mixture of $\mathrm{Cu}^{+}$and $\mathrm{Cu}^{0}$ on the catalyst surface after being used, and Co presents as mixture of $\mathrm{Co}^{2+} / \mathrm{Co}^{3+}$ and $\mathrm{Co}^{0}$. With increasing of sodium addition, the $\mathrm{Cu}^{0} / \mathrm{Cu}^{+}$ratio and the $\mathrm{Co}^{0}$ intensity both decreased. The $\mathrm{CuCoMnNa} \mathrm{M}_{0.1}$ catalyst may be one of the most suitable candidates for the higher alcohol synthesis from bio-syngas because this non-noble metal catalyst can efficiently produce higher alcohols through the hydrogenation of CO. The higher alcohols derived from bio-syngas with higher octane values could be used as transportation fuels or petrol additives. The bio-fuels synthesis is unstinted by the feedstocks of biomass, and potentially, may be one promising route to produce bio-fuels in future.

\section{References}

(1) Navarro, R. M.; Pena, M. A.; Fierro, J. L. G. Chem. Rev. 2007, 107, 3952.

(2) Zhang, Q.; Chang, J.; Wang, T. J.; Xu, Y. Energy Convers. Manage. 2007, 48, 87

(3) Li, H. Y.; Xu, Q. L.; Xue, H. S.; Yan, Y. J. Renewable Energy 2009, 34, 2872.

(4) Czernik, S.; Bridgwater, A. V. Energy \& Fuels 2004, 18, 590.

(5) Zhou, M.; Yan, L. F.; Wang, Y. Q.; Guo, Q. X.; Zhu, Q. S. Chin. J. Chem. Phys. 2005, 18, 69. [周 密, 问立峰, 王益群, 郭庆 祥, 朱清时. 化学物理学报, 2005, 18, 69.]

(6) Tijmensen, M. J. A.; Faaij, A. P. C.; Hamelinck, C. N.; Van Hardeveld, M. R. M. Biomass Bioenergy 2002, 23, 129.

(7) Steen, E. V.; Claeys, M. Chem. Eng. Technol. 2008, 31, 655.

(8) Xu, X. D.; Doesburg, E. B. M.; Sckolen, J. J. F. Catal. Today 1987, 2, 125 .

(9) Verkerk, A. N.; Jaeger, B.; Finkeldei, C. H.; Keim, W. Appl. Catal. A 1999, 186, 407. 
(10) Subramani, V.; Gangwal, S. K. Energy \& Fuels 2008, 22, 814

(11) Li, Z. R.; Fu, Y. L.; Jiang, M.; Hu, T. D.; Liu, T.; Xie, Y. N. Chin. J. Chem. Phys., 2001, 14, 355. [李忠瑞, 伏义路, 姜 明, 胡天斗, 刘 涛, 谢亚宁. 化学物理学报, 2001, 14, 355.]

(12) Zhang, W.; Luo, H. Y.; Zhou, H. W.; Wu, Z. H.; Huang, S. Y.; Liu, C. Z.; Chu, H. P.; Lin, P. Z.; Lin, L. W. Chin. J. Catal. 1999, 20, 285. [张 伟, 罗洪源, 周焕文, 吴治华, 黄世显, 刘 崇早, 初惠萍, 林培滋, 林励吾. 催化学报, 1999, 20, 285.]

(13) Ojeda, M.; Granados, M. L.; Rojas, S.; Terreros, P.; Garcia-Garcia, F. J.; Fierro, J. L. G. Appl. Catal. A 2004, 261, 47.

(14) Boz, I. Catal. Lett. 2003, 87, 187.

(15) Tien-Thao, N.; Zahedi-Niaki, M. H.; Alamdari, H.; Kaliaguine, S. J. Catal. 2007, 245, 348

(16) Dalmona, J. A.; Chaumetteb, P.; Mirodatos, C. Catal. Today 1992, 15, 101.

(17) Su, Y. L.; Liu, B.; Pei, S. P.; Wang, X. Y.; Liu, Z. M. Chin. J. Catal. 2004, 25, 683. [苏运来, 刘 博, 裴素朋, 王向宇, 刘中 民. 催化学报, 2004, 25, 683.]

(18) Xu, R.; Wei, W.; Li, W. H.; Hu, T. D.; Sun, Y. H. J. Mol. Catal. A 2005, 234, 75.

(19) Gupta, M.; Spivey, J. J. Catal. Today 2009, 147, 126.

(20) Chen, X. P.; Wu, G. S.; Wang, X. Z.; Sun, Y. H.; Zhong, B. Chin. J. Catal. 2000, 21, 301. [陈小平, 吴贵升, 王秀芝, 孙予 罕, 钟 炳. 催化学报, 2000, 21, 301.]

(21) Li, D. B.; Qi, H. J.; Li, W. H.; Sun, Y. H.; Zhong, B. Acta Phys. -Chim. Sin. 2006, 22, 1132. [李德宝, 齐会杰, 李文怀, 孙予罕, 钟 炳. 物理化学学报, 2006, 22, 1132.]

(22) Ma, X. M.; Lin, G. D.; Zhang, H. B. Chin. J. Catal. 2006, 27, 1019. [马晓明, 林国栋, 张鸿斌. 催化学报, 2006, 27, 1019.]

(23) Sugier, A.; Freund, E.; Malmaison, R. Process for Manufacturing Alcohols and More Particularly Saturated Linear Primary Alcohols from Synthesis Gas. US Pat. Appl. 105312, 1981.

(24) Spivey, J. J.; Kumar, C. S. S. R.; Balaji, G.; Subramanian, N. D. Catal. Today 2009, 147, 100.

(25) Xu, H. Y.; Chu, W.; Deng, S. Y. Acta Phys. -Chim. Sin. 2010, 26, 345. [徐慧远, 储 伟, 邓思玉. 物理化学学报, 2010, 26, 345.]
(26) Mehr, J. Y.; Islami, M.; Peyrovi, M. H.; Mahdavi, V. Appl. Catal. A 2005, 281, 259.

(27) Zhang, H. B.; Dong, X.; Lin, G. D.; Liang, X. L.; Li, H. Y. Chem. Commun. 2005, 5094.

(28) Kan, T.; Xiong, J. X.; Li, X. L.; Ye, T. Q.; Yuan, L. X.; Torimoto, Y.; Yamamoto, M.; Li, Q. X. Int. J. Hydrog. Energy 2010, 35, 518.

(29) Yuan, L. X.; Chen, Y. Q.; Song, C. F.; Ye, T. Q.; Guo, Q. X.; Zhu, Q. S.; Torimoto, Y.; Li, Q. X. Chem. Commun. 2008, 5215.

(30) Ye, T. Q.; Yuan, L. X.; Chen, Y. Q.; Kan, T.; Tu, J.; Zhu, X. F.; Torimoto, Y.; Yamamoto, M.; Li, Q. X. Catal. Lett. 2009, 127, 323.

(31) Liu, Y.; Chen, F.; Zhuang, S. X.; Wang, J. J.; Ma, R. G. A Method and Equipment for Preparation of Syngas from Solid Biomass. CN Patent CN101191060A, 2007. [刘 勇, 陈 枫, 庄叔贤, 王家俊, 马仁贵. 一种由固体生物质制备合成气的方 法和设备: 中国, CN101191060A [P], 2007]

(32) Aquino, A. D.; Cobo, A. J. G. Catal. Today 2001, 65, 209.

(33) Chen, B. S.; Zhao, J. S.; Zhang, L.; Xiong, G. X.; Sheng, S. S. Chin. J. Catal. 1990, 11, 265. [陈宝树, 赵九生, 张 墟, 熊国 兴, 盛世善. 催化学报, 1990, 11, 265.]

(34) Li, S.; Li, A.; Krishnamoorthy, S.; Iglesia, E. Catal. Lett. 2001, 77, 197.

(35) Mross, W. D. Catal. Rev. Sci. Eng. 1983, 25, 591.

(36) Courty, P.; Durand, D.; Freund, E.; Sugier, A. J. Mol. Catal. 1982, 17, 241.

(37) Laan, G. P. V.; Beenackers, A. A. C. M. Catal. Rev. Sci. Eng 1999, 41, 255.

(38) Sachtler, W. M. H.; Ichikawa, M. J. Phys. Chem. 1986, 90, 4752.

(39) Dry, M. E. Catal. Today 2002, 71, 227.

(40) Huang, X.; Curtis, C. W.; Roberts, C. B. Fuel Chemistry Division Preprints 2002, 47, 150.

(41) Schulz, H. Appl. Catal. A 1999, 186, 3.

(42) Yang, B. L.; Chan, S. F.; Chang, W. S.; Chen, Y. Z. J. Catal. 1991, 130, 52.

(43) Li, D. B.; Yang, C.; Li, W. H.; Sun, Y. H.; Zhong, B. Top. Catal. 2005, 32, 233.

(44) Velu, S.; Suzuki, K.; Gopinath, C. S. J. Phys. Chem. B 2002, 106,12737 